\title{
EMERGENCY SURVEY ON DISMANTLING OF FORMER RESIDENCE OF KIUCHI JUSHIRO IN THE HELLS OF KOUNODAI, ICHIKAWA CITY
}

\section{市川市国府台丘陵における旧木 内重四郎邸の解体に伴う緊急調 査について}

\author{
Youetu FUJIYA $-* 1$ \\ Tomohiro ONDA $-* 3$
}

Masahiro NAKATA $-* 2$

\section{Keywords :}

History of modern housing, Modern japanese architecture, Preservation, Emergency survey, Yasuoka Katuya, Kashima Sadafusa

キーワード :

近代住宅史，近代和風建築，保存，緊急調査，保岡勝也，鹿島貞房

\author{
藤谷陽悦—*1 \\ 恩田友浩 — $* 3$ \\ 中田雅弘 — $* 2$
}

本研究は市川市国府台丘陵に建っていた木内重四郎邸の緊急実測調査につ いて報告したものである。木内は貴族院議員・京都府知事を歴任した政治家 で，自分が余生を送るためのものとして大正 3 年にこの住宅を建設した。建 物については和館部を保岡勝也, 洋館部を大蔵省臨時建築局技師の鹿島貞房 が担当し, 和洋折衣様式と洋館部ではゼセッション様式か加味されるなど, 日本の近代住宅史を考えるうえで重要な建物であった。この建物崔民から の積極的な働きかけで保存活用も検討されてきた。しか，土地取得の問題 から平成11年 5 月に取り壊された。本来ならば，こうした地域の歴史を表わ す貴重な文化遺産は早めに価值を見出して, 記録に残すす法を講ずるべきで あったと考えている。本稿では木内邸の緊急調査について報告すると.同時 に，今後の行政側が考之得るべき対応について提言を行うものである。
The recent spread of the notion of a registration system for cultural assets has led to a wider recognition of the significance of historic landmarks. Many of these are housing structures, of which large numbers are being destroyed owing to differences in the interpretation of the recognition of registration system in each municipality. This especially holds true for regions that have not been researched by the Agency for Cultural Affairs, where although the significance of these examples of modern Japanese architecture is recognized, the lack of adequate measures to conserve them has led to their permanent loss. The former second residence of Kiuchi Jushiro (a member of the House of Peers) in Kounodai was a rare example of historic architecture in the city of Ichikawa that had survived both the Great Kanto Earthquake and the War. The structure was located at Mamayama overlooking the Edo River and former area of Tokyo Bay. The house, surrounded by woodland, was located amidst beautiful scenery, beautiful scenery, and constituted a rare suburban example of housing in which Japanese and western style structures are placed adjacent to one another. After the War, the house left the hands of the Kiuchi family, and became a dormitory for the families of employees of the Kajima Corporation. During its later history, there have been plans for the city of Ichikawa to buy it and convert it to a museum, but these were abandoned due to financial difficulties. In May 1999 (Heisei 11) the structure was destroyed. Essentially, these types of structures should be preserved on sight, and if that is not possible, then a record should be kept of them. In the case of this structure, the author was able to conduct a 3-day measured survey with some of his students in December 1998 (Heisei 10), and from this research it was found that the house was a rare structure that illustrated the character of villas in the city of Ichikawa and the aristocratic life of the time. This paper aims to report the information obtained through our survey, and to offer proposals about how historic structures ought to be preserved.

The research domain of this report indicates that the focus on modern Japanese architecture has caused a notable decline in the maintenance of historical architecture. Also, the main materials that are used are books and scholarly papers written in Japanese.
If the original language of Such materials is Japanese, it is reasonable to use the materials in its original form. However, the world of Japanese education presently rides the wave of internationalization and is quickly recognizing the importance of contents written in other languages and aims to make provisions for them. With this primary goal in mind, some believe that contributions should be made to international journals. The subject of history is the realm where the founding of the nation and the ways of regional culture is studied, but the presentation of knowledge is limited. Furthermore, if you think about the procedures of investigative reading, the scope of the presentations is even more narrowed. Without serious thought, the author cannot so easily agree to such a single-minded approach to the present state of internationalization. Also, in order to make Japanese architectural history a specialty, there should be no complacency regarding the writing of information in international languages. In addition to a placing himself in the educational world, the author strives to further understand by harmonizing the current situation with the era. There may be many troubling points for the reader. However, a reader should present information along with their criticism in international languages.

\section{Kiuchi Jushiro, member of House of Peers}

The owner, Kiuchi, Jushiro was born in Chiyodamura of Musa County (present Yotsukaido-shi), Chiba Prefecture on December 10, 1865(Keio 1). His father was Kiuchi, Jyubei, from a renowned affluent family. $* 1$ According to Kiuchi Jushiroden, "biography of Kiuchi Jushiro", young Kiuchi was not physically strong and did not prefer to play outside with other children. His grades at school were excellent which he topped on both elementary and middle school. After he had graduated, he desired to attend a university in Tokyo, and although the death of his two brothers have at one time forbade him to further attend school, he had asked Yamatoku Kikujiro (alias Ishii Kikujiro, later Minister of Foreign Affairs) for adoption and fulfilled his desire. He is said to have moved to Tokyo as if to flee. The record says that along the way to Tokyo to attend the Tokyo Imperial University, he had stopped at Kounodai terrain and swore to fulfill his high ambitions.

\footnotetext{
*1 Assoc. Prof., Dept. of Architecture Eng., College of Industrial Technology, Nihon Univ., Dr. Eng.

*2 AMAMIYA Architect Plan Office Co., Ltd.

*3 Student, College of Industrial Technology, Nihon Univ.
}

*1 日本大学生産工学部建築工学科 助教授 $\cdot$ 工博

(干275-8575 習志野市泉町1-2-1)

*2 (侏)雨宮建築設計事務所

*3 日本大学生産工学部建築工学科 
In 1888 (Meiji 21), he graduated Law and Literature College of Tokyo Imperial University, and then given a post as an assistant counselor at Cabinet Legislation Bureau. After that, he had served on posts such as Director General of Commerce and Industry Bureau at the Ministry of Agriculture and Commerce, and Councilor to Superintendent Office, however, they were not positions envisioned by Kiuchi who had hoped to be a politician. In January 9, 1892 ( Meiji 25) he married Yataro Iwasaki's second daughter, Isoji, and the following year, through mediation of Takaaki Kato, his brother in law, he was given a position as secretary in both Interior Ministry and House of Peers. He served various other posts. One was the post as the Director General of Department of Agriculture, Commerce and Industry of the Superintendent Office in Korea, which he served for 5 years from 1906 (Meiji 39) during which he had worked on the annexation issues of Korea. Later, in 1911 (Meiji 44), he was appointed as a member of House of Peers. These periods were the most spectacular times of his career. In 1912 (Meiji 45), he constructed his long aspired second house in Kounodai. In 1916 (Taisho 5) he was appointed as Governor of Kyoto Prefecture, but later he was embroiled in a bribery case pertaining to transfer of Kyoto Joshigakko, Kyoto Women's College, which terminated his term in 1918 (Taisho 7). In his later life, his efforts were put into appointing his brother in-law Kato Takaaki as the Prime Minister, utilizing a broad human network constructed during his period as the government officials. In December 18, 1924 (Taisho 13), he was diagnosed as typhoid, and in January 18, 1925 (Taisho 14), he deceased, his wife and children at his deathbed. It is said his bones were buried in a charnel of the second house.

2. The Designer of the Structure

Due to the urgent dismantling of the structure only the measurement of the structure and confirmations of the remains were performed. Furthermore, roof trust was examined, and in this occasion, munafuda, a board on which constructors are listed, was discovered in the loft of the tower that has an inscription of a following content: (See Figure-1)

\section{Munafuda (front side)}

Ordered by Kiuchi Jushiro

Started June 1912 (Meiji 45), completed July 1914 (Taisho 3)

Designing advisor of Japanese-style mansion: Yasuoka Katsuya Designer of Western-style mansion: Kajima Sadafusa

Accountant: Ushio Yaheiji and Matsumoto Shinnosuke

Director: Takeuchi Jutaro

Director: Hirose Tokutaro

Master builder: Shimazaki Seitaro

Facilitator of carpenters: Rokutaro Nakano

Carpenters: Shimizu Jintaro, Hosoya Washiji, Tsujimura Yasuhei
Fukino Ichitaro and Yabe Ryuzo

(Back side) Nakakita Shoukichi and his apprentice, Hagishima Zenshichi and his apprentices, Wakatsuki Masunosuke and his apprentices

Fujiwara Kamekichi,and Yahata Kintaro.

Water sanitary construction: Suga Corporation

Electrical work: Harayasu Corporation

Lumber: Harashima, Tokichi

Sawyer: Imai Inosuke

Shingle Roofing: Yokoyama Umekichi

Slate Roofing: Iwade Shinnichi

Earthworkers: Koide Iwamatsu and his

Apprentices: Kawai Ginjiro

Glass: Hishida Shotaro

Gardener: Nakamura Kichitaro and Asaga Shinsuke

Transport: Suzuki Kenkichi

Earthwork: lioka Tousuke

Bricks: Masuda Morinosuke

Wells: Ishihara Teikichi

Garden Plant: Higure Sobei

Paintwork: Oosawa Gentaro

The structure outline is as follows:

[Structure Outline]

Owner: (former) Kiuchi Jushiro

Location: 4-11-4, Mama, Ichikawa-shi, Chiba Prefecture

Date of construction: started June 1912 (Meiji 45), completed July 1914 (Taisho 3)

Designer: Designer of Japanese-style mansion, Yasuoka Katsuya; Designer of Western-style mansion, Kajima Sadafusa; Director: Takeuchi Jutaro

Contractors: Takeuchi Jutaro and Hirose Tokutaro

Characteristics of the structure:

Western-style mansion-wooden, 2 floors, with a tower roofing;

Japanese-style mansion-wooden, flat, storehouse-wooden, 2 floors

Here we can see that 2 designers, 2 directors, 1 master builder, 5 carpenters, 7 workers, 2 gardeners, and 6 other construction-related workers were involved in the construction of this residence. Out of these listed, the 2 designers were found on Zenkoku Doboku Kenchikujinmeibo (Who's Who of All Japan Civil Work and Architecture)(Doboku Kenchiku Kogeisha, April, 1934).

Yasuoka Katsuya, the designer for the Japanese mansion, was born on January 22, 1877 (Meiji 10). In 1897 (Meiji 30), he entered the Department of Architecture of Tokyo Imperial University and graduated in March of 1900 (Meiji 33); his theses title were "Design for a National

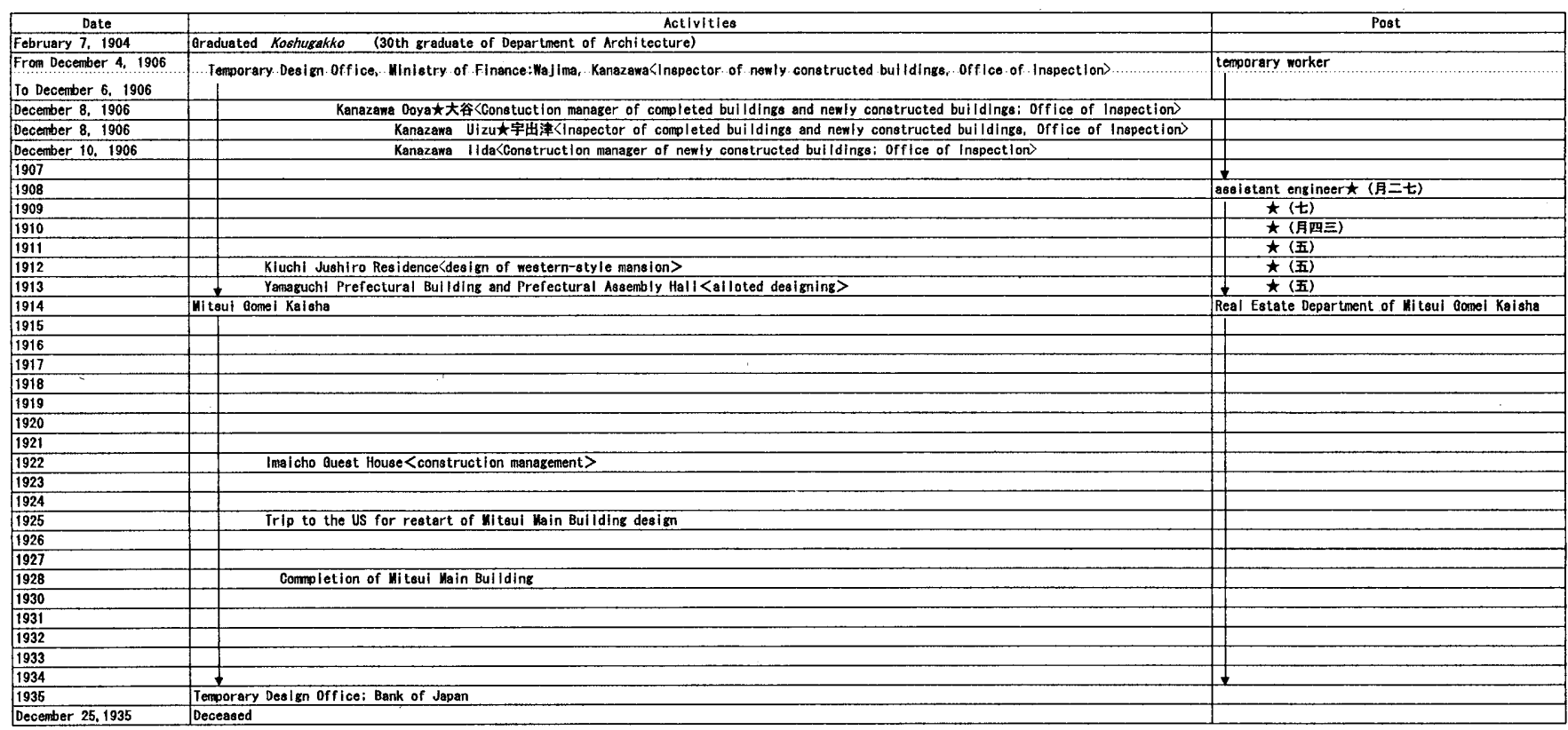

Table-1 Abbreviated chronological table of Kajima Sadafusa 
Bank", and "Few Glimpse on the Bank Building", both on bank architecture. From 1900 (Meiji 33) to 1905 (Meiji 38), he worked under Sone Tatsuzo and there, he had worked on matters relating to Mitsubishi. Further in 1905 (Meiji 38), he had entered Mitsubishi Marunouchi Office, and the following year, he was appointed as chief engineer. From 1907 (Meiji 40) to 1909 (Meiji 42), he studied in Europe, and later in 1911 (Meiji 44) despising working at a company, he had quit Mitsubishi Marunouchi Office. Yasuoka opened his own architectural firm at Marunouchi in 1913 (Taisho 2), and there he designed centrally, banks, commercial buildings, and housings. $* 2$ He was famed mainly as a "housing architect". From late Meiji Period, business workers had greatly increased in Tokyo, and as a result, housings have been built in the suburban region. The city of Ichikawa, a typical residential region for the business workers, and Yasuoka's commission had been these business workers. However, former Kiuchi residence was Yasuoka's earlier work, of the time he was working for Mitsubishi Marunouchi Office. Kiuchi Jushiro got married to a daughter of Iwasaki family of Mitsubishi, and it is probable that from this connection, the construction was commissioned. From around 1915 (Taisho 4), Yasuoka started to write about housings; this structure which was completed around the same time, may be thought of as his starting point as an architect.

Kajima Sadafusa (See Table-1), the designer of the western-style mansion, graduated Division of Architecture at Koshugakko in February of 1904 (Meiji 37) as one of the $30^{\text {th }}$ batch of graduates. Later, in December 1906 (Meiji 39) he entered in the Temporary Design Office of Ministry of Finance, and from 1908 (Meiji 41) he became the engineer of the department. Kiuchi Jushiro residence was designed during this time. In 1916 (Taisho 5), he had designed among Takeda Goichi and Ookuma Yoshikuni, his superiors, on Yamaguchi Prefectural Building and Prefectural Assembly Hall. $* 3$ Temporary Design Office has ceased to exist in 1913 (Taisho 2), their legal operations transferred to Temporary Design Office of Secretariat of Minister of Finance. During this time the real estate division of Mitsui Gomei Kaisha. was established. Kajima had transferred to Mitsui during the construction of Yamaguchi Prefectural Building and Prefectural Assembly Hall. At Mitsui Gomei Kaisha, Kajima had served as a construction facilitator of Imai Guest House. In 1925 (Taisho 14), he had served as the negotiator in the United States for the construction of Mitsui Main Building. It seems that he was not involved in the actual design during his Mitsui days. $* 4$ His greatest efforts were put into the Yamaguchi Prefectural Building and Prefectural Assembly Hall which are manifestations of Secession style architecture. It can be assumed that Kajima, under the supervision of Goichi Takeda and Yoshikuni Ookuma, had improved his skills as architect, and Kiuchi's western-style mansion which has a strong influence of Secession style architecture is one of Kajima's major works.

\section{Kiuchi Residence Structure}

Plans: This housing was created during Kiuchi's ripening stage in life; it was started in June 1912 (Meiji 45), when he was a member of House of Peers and completed in July of 1914 (Taisho 3), when he served as Governor of Kyoto Prefecture. Kiuchi Jushiro Den (Biography of Kiuchi Jushiro) (1937; Showa 12), writes that he had long aspired the aristocratic life of bureaucrats, and from his time as the director-general of Chamber of Commerce and Industry, he had borrowed money and gradually bought the 33,000 square meters $(10,000$ tsubo of land in Table-1 Abbreviated chronological table of Kajima Sadafusa Kounodai terrain that he had once viewed the sunset.

On the east side of Kounodai Shrine is a narrow road, and the concrete wall continues to the gate as if to surround the building. The main gate is simple, and upon entering there is a mortar storehouse on the right. The approach to the entrance makes a mild curve. In the entrance grows a large chinquapin tree. A road is created surrounding the tree, which functions as a driveway. In the front is the cottage like structure with large tower roof. Porte-cochere has a modest design, which the gable comes down low like an eave. Overall, the design of the building is reminiscent of an English country house.

Ground Plan: The ground plan of this house is as shown in the Figure-2. The structure was completed in 1914 (Taisho 3), but the house is constructed in a manner where the Japanese and western style mansions are adjacently placed which was often seen in mansions of the Meiji era. On the side of the entrance is a western-style mansion which has a connecting passageway that is placed between the two mansions. The Japanese style mansion is located behind the western-style mansion. The western-style mansion has a wooden floor and the floor of the connecting passageway is covered with $81 / 2$ ken of linoleum (ca.6.3 m) which probably was laid for changing to (slippers) when transferring from a floor-based life of living in the Japanese mansion to shoe wearing style of living in the western-style mansion. The Japanese-style mansion is laid out in a quadrangle, ambulatory style with a garden at its center; the south side a guestroom, the west side a private living room, and the north side is the maid room and the kitchen. The garden is a grass laid western garden, presumably used for parties. This type of ground plan where the Japanese style structure is quadrangle and the accompanying westernstyle structure is built parallel to the structure, was a typical style of Meiji Period mansions; former Kiuchi residence is a rare housing that reflects the ideal style of the aristocratic life.

Exteriors-western-style mansion: The western-style mansion is a wooden, 2 floored building which is situated facing the southern and the eastern side of the garden. It is linearly structured, laid on the northsouth axis. The exterior is built in a cottage style, with ochre stucco outer wall and slate roofing. Wooden bracket-like decoration is placed on the eaves. The foundation is comprised of facing bricks, which on the upper part has granite camber and the drain. The exterior wall is hand spread to give the structure a simple and quiet country house touch. The openings of the exterior wall are two rows of upper and lower windows that have molded decoration. The eaves on the east side protrude toward the exterior with a smooth, almost twining curve, reminding us of the Art Nouveau design. The eaves of the porte-cochere show a molded framing styled so that the perpendicular and horizontal lines are emphasized in a Secession manner. This type of lively design was a technique favored by the designers of Temporary Design Office of Ministry of Finance, namely Tsumaki Yorinako and Takeda Goichi.

As previously stated, the designer of this western-style mansion was Kajima Sadafusa who had at one time served in the Temporary Design Office. He, along with Takeda Goichi, had worked on the Yamaguchi Prefecture Building in 1917 (Taisho 6) and was likely familiar with the techniques of Secession style.

\section{Room Arrangement and Interior Design}

Western-style mansion: The western-style mansion is comprised of entrance, living room, study, and veranda. The entrance has a stucco ceiling and mosaic marble space where one puts off shoes. Ascending the stairs, one reaches the entrance hall. The interior wall of the entrance hall and the hallway is covered with cream, vertically striped fabric. The frontal side of the entrance hall is finished with plywood that emphasizes the vertical bars, and on the upper part, there is a curvilinear glass fanlight. Carpeted floor, the stucco wall with a circular decoration, and the glass lighting hanging from the ceiling all give a profound beauty.

The interior decoration of the living room (See Figure-3) is simple in its composition. The walls are covered with cream, vertically striped fabric, and on the southern side is a display shelf and beneath it is a Franklin type fireplace of the "most welcoming size." The flooring is plank with the parqueted outer sides, but the remnants of glue and red oxide on the outer sides suggest that the floor may have been carpeted at the time of completion.

Study is more extravagant as compared to the simple living room. The entire floor is parqueted and has a coffered ceiling. The north side is a display shelf and a green tiled Franklin type fireplace. On the upper part of the fireplace is an openwork screen with a landscape painting of an unknown period that adds an extravagant touch to the space. The wallpaper is covered with floral motif. The parquet decoration of the fireplace and the display shelf emphasizes the perpendicular line, and the screen on the upper part of the bay window has a partition of wave design, giving an overall atmosphere of Secession style. The floral design wallpaper may have been imported from Morris \& Co. $* 5$

Japanese style mansion: The Japanese-style mansion is laid out in a quadrangle, ambulatory style. (See Figure-4) Living room, private living room, kitchen and maid room surround the center garden. The 


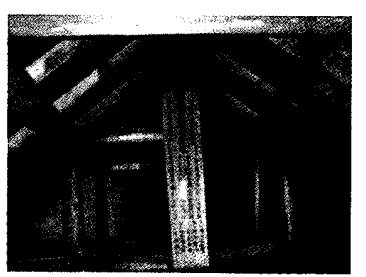

Figure-1 Munaita found at the western-style mansion of Kiuchi residence

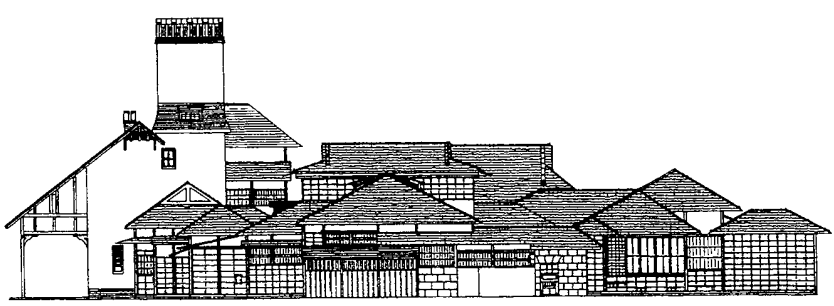

north

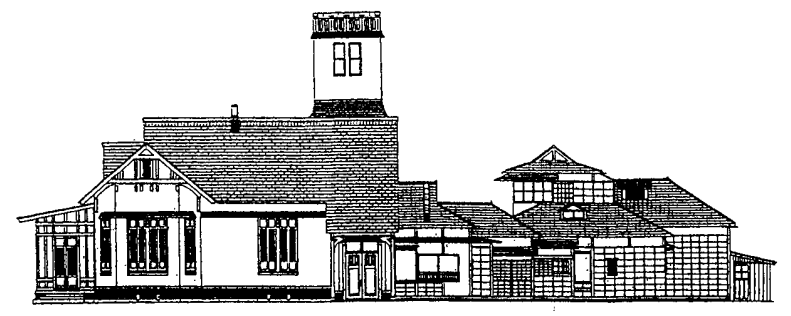

east

Figure- 6 Elevation view of east and north façade

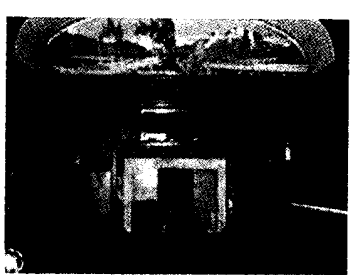

Figure-3 Interior of drawing room

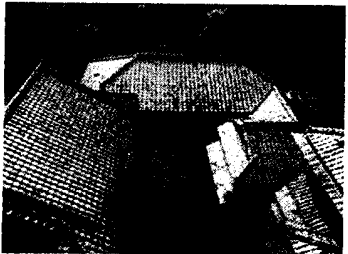

Figure-4 Arrangement

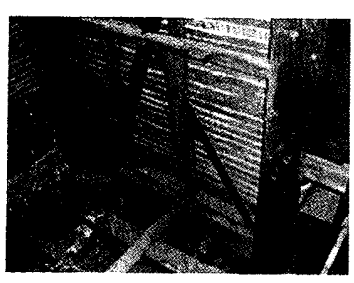

Figure-7 Roof truss of western -style mansion
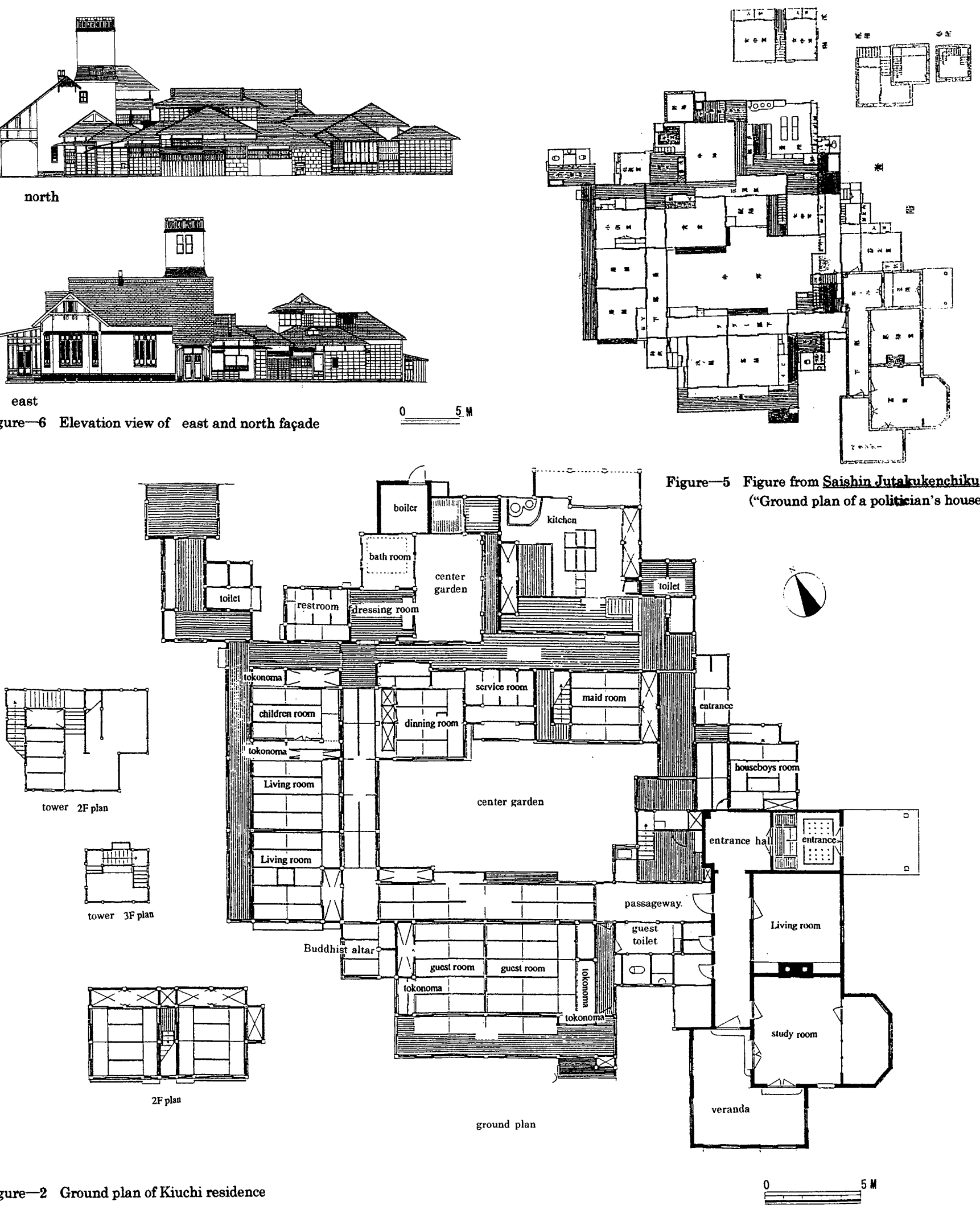
connecting passageway between Japanese and western style mansions has linoleum flooring, and on its way there is a guest bathroom with a flushable toilet. The lower part of the guest toilet room is covered with sanitary ceramic, which suggests a partial renovation. The toilet, labeled "T\&S TRADE MARK PATENT" indicates that it was imported from abroad. The guestroom on the south is composed of a drawing room $121 / 2$ jo and the subsidiary room 10jo. The alcove has alcove shelves and other shelves ( tokowakidana, chigaidana and tsukeshoin), taking the shape of a Japanese shoin (typical study) style. On the room wall screens (osaranma) and horizontal pieces of timber (nageshi) are installed to express a typical shoin style. In the hallway of the adjacent room, tsukeshoin and tokodana are also arranged so that the view toward the garden is emphasized. The exterior part of rooms (irigawa) is plank and has four sheets of tatami on the inner side. The eaves of the roofing protrude about $121.2 \mathrm{~cm}$ (4 shaku). The flooring was designed so that the exterior part was floored with plank that will not be affected by rain and the inner part with tatami. Between the drawing room and the living room is a space for Buddhist altar of a size of $3 j$, and open to sunshine from the southwest. On one side of wall a Nichiren sect Buddhist altarpiece was placed; it is said that the mistress sometimes prayed here.

Living room on the west is comprised of $11 j \mathrm{jo}, 10 \mathrm{jo}$, and $8 j 0$ rooms. The interior of the living room is created in a more casual, sosho style or sukiya shoin style that contrasts with the "somewhat grim and formal, kaisho style" (Saishin Jutakukenchiku (Modern Housing), 1923; Taisho 12). The 11 jo room facing south has a built-in heating (horigotatsu). The 10jo room in the center has an alcove, forming a relation of [main(zashiki)+subsidiary(tsuginoma)] including the 8 jo room. This room, which is located near the guestroom and takes in abundant sunshine, was probably used by the master as his study and living room. The 8 jo room on the north has a built-in chest and an alcove, presumably planned for use as children's room.

On the north side, across from the center hallway are kitchen and dining room. Next to the sunny room facing the center garden are the dining room, the service room, and the maid room. The dining room on the southwest, adjacent to the service room, has the most sunshine, and a fire pit is provided, which suggests its use as the room for the ladies. The north side has the bathroom, the restroom, the dressing room, and the kitchen. The restroom is created like the sukiya style, therefore, may have been the ladies' powder room. There is a large space of earth floor at the kitchen where the basin of the city water system was placed. The basin is at the center of the earth floor, and on the east and the west corner are stoves. The shelf on the west is built-in, and the ceiling has a skylight for smoke exhaustion with a window that opens upward. These facilities were modern at the time. The modernization of kitchen spread through the upper class around 1902 (Meiji 35) from Ookuma Shigenobu who had installed modern kitchen facilities in his residence. Iwasaki family, who had a marital relation with Kiuchi Jushiro, also had a housing famed for its modern kitchen. These factors probably have led to the installation of modern kitchen facilities in the Kiuchi housing.

Tower: This is located at the back of the entrance hall. The entrance is adjacent to houseboy's room on its east, and there is also a side door on the east side. The first floor of the tower also functions as a hall that connects the flow of side door and the connecting passageway. On the first floor, there is a display shelf along the backside of the entrance hall and spiral staircase. Second floor is comprised of itanoma, room with a wooden floor, and a small parlor. Third floor is a small room with a bench placed facing the south side that overlooks Edo River. From this it may be induced that the tower itself was built as a belvedere to watch over Bay of Tokyo and Edo River.

\section{Yasuoka Katsuya and his relation to Kiuchi residence}

Muneita shows Yasuoka's role as "designing advisor of Japanesestyle mansion." This suggests his role as a supervisor of both of the mansions of Kiuchi residence. Yasuoka, the "pioneer of housing architecture" is known to have written numerous writings pertaining to housing *6, and in one of them, Saishin Jutakukenchiku (1923 Taisho 12), there is a housing plan of what seems to be his design, "Figure $210 \mathrm{~A}$ ground plan of a politician's house" (Figure 5). "A politician's" ground plan that is shown here exactly coincides with the measured drawing of Kiuchi residence. This indicates that the house has maintained its shape without major alteration since its completion. In Yasuoka writing, "Saishin Juutaku Kenchiku" ("The Latest Residential Architecture"), he describes the ideal layout of a room.

1) Entrance hall "is an essential part of the building that will be continually used, therefore, its interior should be designed in a way so that it would not bring unpleasantness or satiety." If a room is spacious, "you can furnish it with such things as a table and chest. A flower vase would also be a wonderful accent." (Shojuutaku no Yofu Soshoku (Designs of a Small Japanese Style Residence), 1925, Taishoo 14)

2) Parlor should be "unless it is a special case, it should be somewhat grim and formal, taking kaisho style." Generally in a Japanese-style residence, "one room is usually between ten to twelve mats and the second room is between eight to ten mats. But the layout of this room would be five to six shaku ( 1 shaku = approximately 0.303 meters). Mats should comprise three shaku(s) of the room and wooden floors made of small planks should be laid in the remainder. Through this technique, good aesthetic form can be achieved in addition to practicality."

3) Yasuoka's view of the living room is that there should be two separate rooms for the master and the mistress, which master's room shall also "serve as a study" and the mistress's as chanoma, the dining room. The mistress's room which literally functions as the dining room is generally located distant from the living room and usually used for family gathering, hence, this room should be located, from the family oriented perspective, in a space where comfort, view, and sunshine is most suitable. To summarize this passage, the functions of the dining room are:

(1) Ventilation and lighting should be optimal. Glumness should be avoided and instead, liveliness should be pursued.

(2) It is usually necessary for dining room to be located in such place where it overlooks most places.

(3) If the room is in Japanese style, then there should be plenty of oshiire, storage space.

(4) If possible, there should be more than one source for natural lighting.

(5) If the kitchen and the maids' room are distant, then supervision will turn lax.

4) The water and sewage should be installed to an ideal standard. Hence, it is desirable to make all toilets, both Japanese-style and Western-style, flush toilets. In addition, Japanese people will dually utilize Japanese-style and Western-style clothing from now on. Therefore, it is recommended that an area be set aside for the removal of the hakama, at least for the guests.

(1) The design of western-style mansion and entrance hall is based on simple Secession style.

(2) Parlor is created in shoin style reflecting "shin" of kaisho.

(3) Mistress's room, which is also chanoma, faces south through the center garden, takes in abundant sunshine, and has openings both on east and west side. Chanoma, which is also used for dining, is adjacent to the maids' room. It is located across the kitchen, suitable for supervision and housework.

(4) Sanitary facilities used were the water supply in the kitchen and sewage for the bathroom area. The place for washing one's hands was designed spaciously, used also as a place to remove one's hakama. This area accommodated a lifestyle in which both Japanese-style and Western-style clothing was worn.

As described above, Kiuchi residence contains many of the elements that Yasuoka Katsuya has asserted on housing. Plan and interior design of Kiuchi residence may be thought of as the manifestation of his theory.

6. Tower 
Another characteristic of Kiuchi residence is the tower placed between the two mansions. The topmost floor of this tower is belvedere, which one is able to go out from the roof to a watchtower using a door with a pulley. As seen the elevation view (Figure-6), the design of this tower lacks cohesion with the balance of entire structure. The north and west façade, for example, is designed so that the tower's façade is perpendicular to the braced frames. Further, there was an evidence of mortise and a cut in the midstream of ridgepole in roof truss of the western-style mansion and addition of a new material. From these, it is evident that the connecting section of the western-style mansion and the tower had been remodeled some time in its history. Plan seen in Saishin Jutakukenchiku (1923,Taisho 12) already contains the tower portion. If there has been a aremodeling of the structure, then presumably, it has been performed not after its completion, but during the construction. Kiuchi seemed to have had an exceptional interest in construction and design, and he had repetitively intruded in its design. When the structure was completed, he immediately invited Kentaro Kaneko and together climbed up on the tower one moonlit night to "feast". $* 7$ It is assumable that Kiuchi was very fond of this tower. On the $3^{\text {rd }}$ floor, there is a built-in two-seater bench that faces Edo River. Rooftop watchtower also overlooks the Edo River. Considering the talent and techniques of the architects Yasuoka and Kajima, it is unlikely that they have initially planned this tower that lacks proportion in the structure's overall picture. Kiuchi Jushiro may have ordered the construction of this tower during the construction. Kiuchi residence is a product of not only the architects' talent and techniques to create it but also a reflection of owner's preference and culture as Genius loci.

\section{Conclusion}

Recently, value of a structure is many of the times measured not only by its decoration or techniques, but its place in history at the region as well. This is prominent particularly in the case with modern architecture, which is unavoidable especially in housing structures.

Value of former Kiuchi residence may be listed as the following:

(1) It is a remnant of two significant architects in the history of modern architects, Yasuoka Katsuya and Kajima Sadafusa that belonged to Temporary Design Office.

(2) Individual names of the associated artisans and workers were found on munafuda .

(3) Secession style seen in the western-style mansion shows the extent and techniques of a young engineer who had been in the Temporary Design Office of the Ministry of Finance.

(4) The extent of material and technique used in housings of early Taisho period, such as the use of steel material or sanitary ware and other facilities can be observed.

However, the structure is most important in that it is associated with historical environment in this region.

Kounodai, Ichikawa City, where Kiuchi residence resides, has been a villa for the celebrities since early Taisho period. This region has first been occupied by the nobility, and later spread to the middle class. Former Kiuchi Jushiro's residence has been the predecessor of such houses. It was constructed in 1914 (Taisho 3). In 1885 (Meiji 18), the training troupe of War Department had transferred to Kounodai, and since 1922 (Taisho 11) when the headquarters of heavy artillery brigade troupe $3 \mathrm{had}$ been placed, the area had developed as a residential area, but Kiuchi Jushiro's residency had preceded these events, and the residence was already famed in the region. 85 Years of Keisei Electric Railway has an advertisement of the following title

"Sale of lot of Keisei Electric Railway Company's land in Ichikawa : Part of Kiuchi family estate in Kounodai, $A$ hill at the back of Tekona Shrine, Lands in front of Yahata Station"

As seen in this advertisement, Kiuchi residence was viewed as a type of status in the region. The residence was destroyed in May 1999 (Heisei
11) because of decrepitude, however, from the nature of the structure, it should have been registered as a cultural asset. Under the guidance of the Agency of Cultural Affairs, a survey on modern Japanese architecture is being taken. However, in areas where the survey has not yet been implemented, many building are being destroyed without adequate assessment of its worth. Recently, there have been many cases where volunteers have joined NPOs aimed at town preservation to assist in the surveys of buildings before its demolition. As a result, there has been a raised awareness and concern on behalf of the town residents regarding historical buildings. On the other hand, public administrators corresponding response has been lagging in areas such as the following:

1) The government does not maintain a list of historical buildings.

2)Organizations such as the Board of Education employ few professionals who understand and appreciate architectural history.

In particular, the fact that there are few experts in architectural history in regional governments is a severe detriment. In these demolition cases, the regional government should have employed architectural history experts. If the regional government's response were adequate, ample information would have been collected, even if preservation were difficult. Volunteers from the community have taken initiative and have formed survey organizations. Likewise, the government should respond to this situation by employing architectural experts. Also, the results of the surveys should be shared widely with the general public. Presently, besides the information presented by architectural history scholars, there are only a few opportunities to share the surveyed information. This report serves to points out the current problem which exists within the government and the importance of taking the opportunity to seriously consider this issue. It is the major role of the government to assure pertinent information regarding architectural history is collected and disseminated.

[Notes]

* 1 Genealogy of Kiuchi Jushiro family (Figure by Nakano, Junko, Department of Lifetime Learning, Educational Board of Ichikawa City)

*2 Anzai Sonoe "On the History of Yasuoka Katsuya and his Work" Architectural Association of Japan (Abstracts of Academic Presentations August 1992)

* 3 "Reports on the Construction of Yamaguchi Prefectural Building and Prefectural Assembly Hall": Journal of the Institute of Japanese Architects. 1917 (Taisho 6)

* 4 Nakata Masahiro and Fujiga Yoetsu "Architecture and the activities of the architect, Kajima Sadafusa": Summaries of Technical Papers of Annual Meeting, Architectural Institute of Japan. September, 2000.

*5 The floral motif backcloth of chairs used at Yamaguchi Prefectural Building and Prefectural Assembly Hall which were designed by Kajima Sadafusa were imported from Morris \& Co.of England.

*6 The following list is the major writings of Yasuoka Katsuya

1912 Shinchiku Shunko kaoku Ruishu

$1915 \quad$ Riso no Jutaku

1923 Saishin Jutaku Kenchiku

1924 Nihonka Shitaru Yofu Shojutaku Obeika Shitaru Nihon Shojutaku
1925 1926

1927

1934

1936
Shojutaku no Yofu Soshoku Kenchiku Chishiki Riso no Jutaku Yofu Kourishoten no Tatekata Wafu wo Shutosuru Secchu Shojutaku Chaseki to Roji Chashitsu to Chaniwa Sukiya Kenchiku Jutaku no Juyo Setsubi Chaniwa no Kenzobutsuu
Fujin Bunko Kankokaj Suzuki Shoten Suzuki Shoten Suzuki Shoten Suzuki Shoten Fujin Bunko Kankokai Suzuki Shoten Suzuki Shoten Yuzankaku Suzuki Shoten Koyosha Suzuki Shoten Sogensha
[2000年10月20日原稿受理 2001年 2 月22日採用決定］ 